\title{
Diminishing the risk on lead and zinc ore regions by subtle modulation of soil properties
}

\author{
A. Sas-Nowosielska $^{1,2}$ and M. Pogrzeba ${ }^{2}$ \\ ${ }^{1}$ Czestochowa Tech Univ, Inst Environm Engn, 60A Brzeznicka St., 42-200 Czestochowa, Poland, \\ a.sasnowosielska@is.pcz.czest.pl \\ ${ }^{2}$ Institute for Ecology of Industrial Areas, 6 Kossutha St., 40-832 Katowice, Poland, sas@ietu.katowice.pl
}

\begin{abstract}
The negative effect of non-ferrous metal emission in Upper Silesian Industrial Region (Poland) on the quality of soil is continuously present. It poses a serious threat on living organisms and is an important factor influencing the level of metal load introduced to human organism. Easy way for diminishing the metal uptake by plants is the amendment application to the soil. Presented study was conducted to evaluate the effect of the introduction of sewage sludge and fly ashes from power station into the medium contaminated soil. Heavy metals in soil were stabilized with a mixture of sewage sludge and fly ashes from the local wastewater treatment plant and power plant. Previously the mixture was tested in terms of the probability of its ecotoxicological impact on plant growth and development. Even low doses of the mixture addition to the contaminated soil caused a observable reduction of lead, cadmium and zinc in leaves of grasses. Soil additives also increased the soil $\mathrm{pH}$.
\end{abstract}

Key words: heavy metals, plant uptake, sewage sludge, fly ash

\section{Introduction}

From the origins of human civilization, non-ferrous metals had been used in various branches of economic enterprises. Nowadays the most important sources of non-ferrous metal pollution in air and soil are the ore flotation and smelting processes. The industrial scale of these processes has resulted in non-ferrous metal contamination on the huge land areas. As these metals may persist in soils, even for hundreds of years, natural attenuation cannot be considered as a realistic solution. This creates a serious problem, which concerns hundreds of hectares of arable land, on which generations of farmers grow crop plants. Metal polluted agricultural soil may create a potential source of groundwater contamination and a hazard for living organisms. The negative effect of toxic metals in soil to living organisms is related to the solubility of metals and their presence in soil solution as well as their accumulation in tissues. Thus, important factors to consider are: metal speciation and concentration, content of organic matter and soil acidity. Lead and cadmium in soils located in vicinity of non-ferrous industry are usually complemented by high concentrations of zinc (Sas-Nowosielska et al., 2010; 2011) which drastically impair plant germination, growth and development.
The co-utilization of fly ashes and sewage sludge with lime was presented as soil ameliorant by Reynolds and al. (2000). A product named Slash was analysed by Rethman et al. (1999) for its properties in pot trials. The results highlighted the beneficial effect of the mixture as fertilizer after its incorporation into the soil. The same was confirmed by Truter et al., (2001). Stabilized municipal sewage sludge by fly ash was used with positive effect for ecological rehabilitation in mining areas (Zhang et al., 2008).

Arable lands located in the vicinity of former lead and zinc industry need solution for diminishing bioavailable forms of metals. The evaluation of possible and cost effective Slash-based strategies for diminishing lead, cadmium and zinc uptake by plants near former lead-zinc industry will be presented.

\section{Material and Methods}

The experiment was conducted on the site located in southern part of Poland, near former lead and zinc plant. Six plots $(1 \mathrm{~m} \times 1 \mathrm{~m})$ with soil material (Tab.1) were established on medium heavy metal contaminated soil (class B; Kucharski et al., 1994) 


\section{Sampling procedures}

Soil material from the plots was collected, mixed and replaced. From each plot, 4 subsamples were taken and located as a pile. 4 subsamples from different parts of the pile were prepared for analytical purpose.

Analysis

Physical and chemical soil properties $(\mathrm{pH}, \mathrm{EC}$, organic matter, texture, total metal concentration (aqua regia extraction) were analysed using standard ISO methods.

Bioavailable fraction of metals was evaluated in airdried soil material, ground $<0.25 \mathrm{~mm}$, extracted with $0.01 \mathrm{M} \mathrm{CaCl}_{2}$ (Houba et al., 1995).

Dried plant material was pulverized and wet-ashed with concentrated nitric acid in microwave system (MDS 2000, CEM, USA). Concentrations of metals were analyzed by flame atomic absorption spectrophotometer (Varian Spectra AA 300) or by inductive coupled plasma spectroscopy (ICP-AES) (Varian, USA).

\section{Preparation of sewage sludge and fly ash mixture}

Coal fly ash originating from fluidized bed of power station and sewage sludge anaerobically digested and dewatered from municipal waste water treatment plant were used and mixed together (fly ash : sewage sludge; variant A-1:1; variant B-3:1 respectively). So prepared soil substitute was tested as a organo-mineral base for plant growth and development with standard Lepidium test.

The mixtures $\mathrm{A}$ and $\mathrm{B}$ were incorporated into plot surface $(25 \mathrm{~cm}$ depth) and mixed with soil at $1 \% \mathrm{w} / \mathrm{w}$, $3 \% \mathrm{w} / \mathrm{w}$ and $6 \% \mathrm{w} / \mathrm{w}$ rates. Data was compared with variant with no additives (control).

Plots were planted with seeds of commercial mixture of grasses with domination of $F$. rubra seeds. After germination and establishing of root architecture plots were naturally watered.

In six weeks aerial part of plants was collected and analysed.

Data was presented as Excel figures. Data interpretation based on the computer software Statistica' 10 analysis. A probability of 0.05 or less was considered to be statistically significant.

\section{Results and Discussion}

It is well known that lead and cadmium as well as their compounds create a risk for living organisms. The issue was and is widely analysed under various aspects (Martelii et al., 2006; Gupta et al., 2010).

Spatial analysis of lead and cadmium distribution (Fig. 1 and Fig. 2) on the studied area, based on the data from the site (70 individual samples collected in a greed $10 \mathrm{~m} \times 10 \mathrm{~m}$ ), has shown that about $70 \%$ of the area is characterized with an average concentration of metals with minor variations.

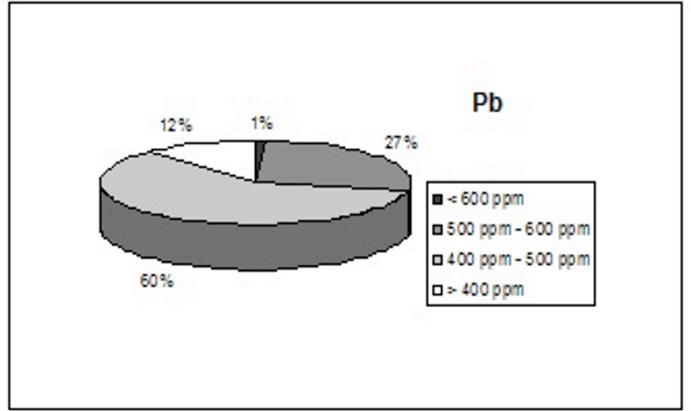

Fig. 1 Soil $\mathrm{Pb}$ concentrations - spatial analysis

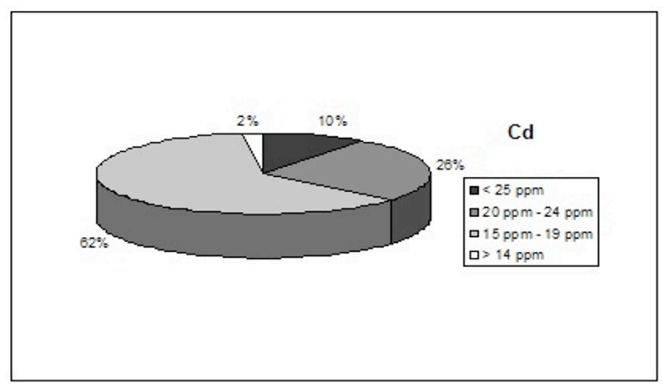

Fig. 2 Soil Cd concentrations - spatial analysis

Fly ash used in the mixture (grain size below 0.063 $\mathrm{mm}$, density of $2.74 \mathrm{~g} / \mathrm{cm}^{3}$ and a bulk density within the range of $0,73-0,93 \mathrm{~g} / \mathrm{cm}^{3}$ ) consist of aluminum silicate, with significant contribution of calcium $(\mathrm{CaO}$ content about $4 \%$ ). The aqueous extract of fly ash used had $\mathrm{pH}$ value of about 13 . The study of radioactivity of the ashes indicated that the waste did not pose the risk to the environment.

Used municipal sewage sludge had slightly alkaline $\mathrm{pH}$ ( $\mathrm{pH} 8.16$ ), approximately $20 \%$ dry matter and $61 \%$ of organic matter. The nitrogen content was at a level of about $2 \%$ whereas phosphorus $\left(\mathrm{P}_{2} \mathrm{O}_{5}\right)$ approximately $5 \%$. Heavy metals, present in acceptable level, were mostly in form of organic or iron and manganese oxides.

The properties and microbiological characteristic of the Slash materials were closed to the garden soil.

The soil (silt loam; Tab. 1) had neutral pH, about 3\% of organic matter, and high levels of bioavailable cadmium and lead.

Tab.1. Physical and chemical soil properties

\begin{tabular}{lc}
\hline \multicolumn{1}{c}{ Property } & Value \\
\hline $\mathrm{pH}(1: 2.5$ soil/ $\mathrm{KCl}$ ratio $)$ & $6.50 \pm 0.14$ \\
$\mathrm{pH}\left(1: 2,5\right.$ soil $/ \mathrm{H}_{2} \mathrm{O}$ ratio $)$ & $6,84 \pm 0,68$ \\
Electrical conductivity $(\mu \mathrm{S} / \mathrm{cm})$ & $141 \pm 22$ \\
Organic matter content $(\%)$ & $3,30 \pm 0.24$ \\
Sand $(1-0.05 \mathrm{~mm}), \%$ & 38 \\
Silt $(0.05-0.002 \mathrm{~mm}), \%$ & 55 \\
$\mathrm{Clay}(<0.002 \mathrm{~mm}), \%$ & 7 \\
\multicolumn{2}{c}{ heavy metals 'pseudo total' concentration } \\
$\mathrm{Pb}\left(\mathrm{mg} \mathrm{kg}^{-1}\right)$ & $397,7 \pm 118,7$ \\
$\mathrm{Cd}\left(\mathrm{mg} \mathrm{kg}^{-1}\right)$ & $17,72 \pm 4,56$ \\
\multicolumn{2}{c}{ heavy metals 'bioavailable' } \\
$\mathrm{Pb}\left(\mathrm{mg} \mathrm{kg}^{-1}\right)$ & $34,9 \pm 4,5$ \\
$\mathrm{Cd}\left(\mathrm{mg} \mathrm{kg}^{-1}\right)$ & $9,18 \pm 0,27$ \\
\hline
\end{tabular}


Contaminated soil amended with Slash material caused the increase of $\mathrm{pH}$ values, especially in variant with amendment A (higher participation of sewage sludge; Fig.3). The significant increase of $\mathrm{pH}$ value after Slash application was observed on sandy and sandy clay loam (Rethman et al., 1999).

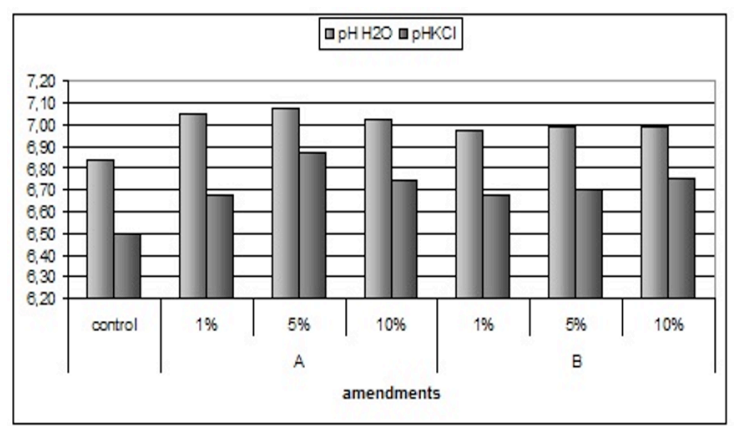

Fig. 3. Values of $\mathrm{pH}$ after application of amendments

After application of amendment A significantly higher values of EC were noticed on variants with $5 \%$ and $10 \%$ of the mixture (Fig.4).

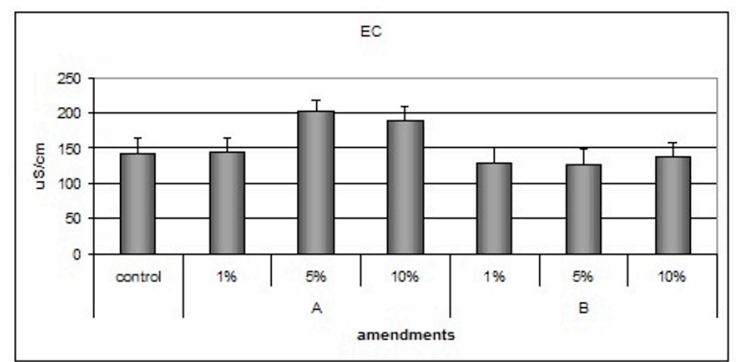

Fig. 4. Values of EC after application of amendments

Application of amendments caused significant decrease of cadmium content in leaves. The effect was observed on variants with the highest doses of amendments (Fig. 5).

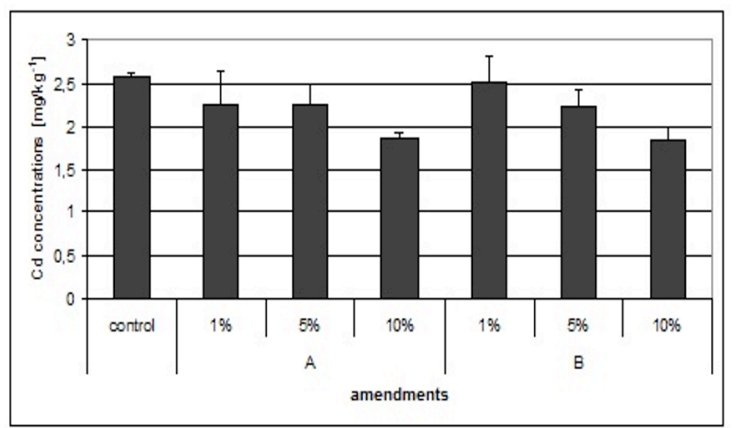

Fig. 5. Content of cadmium in plants after application of amendments

Application of amendments significantly modulated concentration of lead in aerial parts of plants. Decrease of concentration was observed in variants with the highest doses of amendments (Fig.6).

As a result of the addition of different amounts of Slash material to the soil, lower concentrations of easy available forms of cadmium and zinc were noticed. Eventhough the level of bioavailable form of lead in soil was very low, hovewer, after amendment application decrease of metal concentration was observed (data not presented).

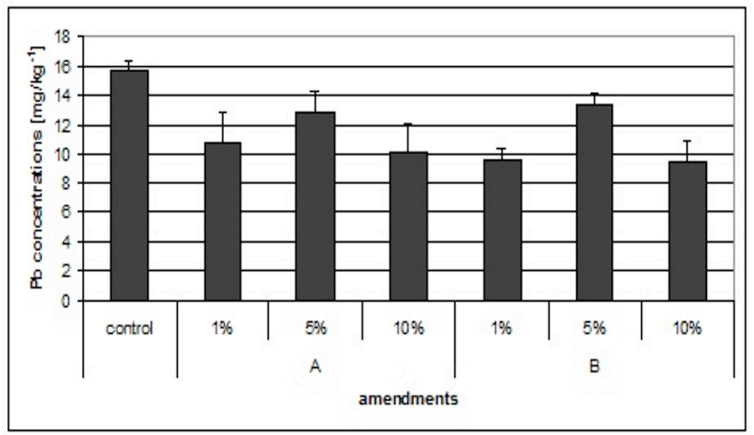

Fig. 6. Values of lead in plants after application of amendments

Lead and cadmium in the studied area were complemented by zinc in plant-stressing concentrations (from $850 \mathrm{mg} \mathrm{kg}^{-1}$ to $1850 \mathrm{mg} \mathrm{kg}^{-1}$ ). The analysis of plant material revealed, that the highest concentrations of zinc were found in leaves with observable signs of chlorosis and necrosis (Sas-Nowosielska et al., 1999, 2000). Data presented on Fig. 7 show decrease of zinc content in leaves after application of the both amendments. The lowest zinc concentrations in leaves were observed on variants with the highest dose of amendment $\mathrm{A}$ and $\mathrm{B}$. The concentrations were lower than the concentrations responsible for plant stress (Mashner, 1995).

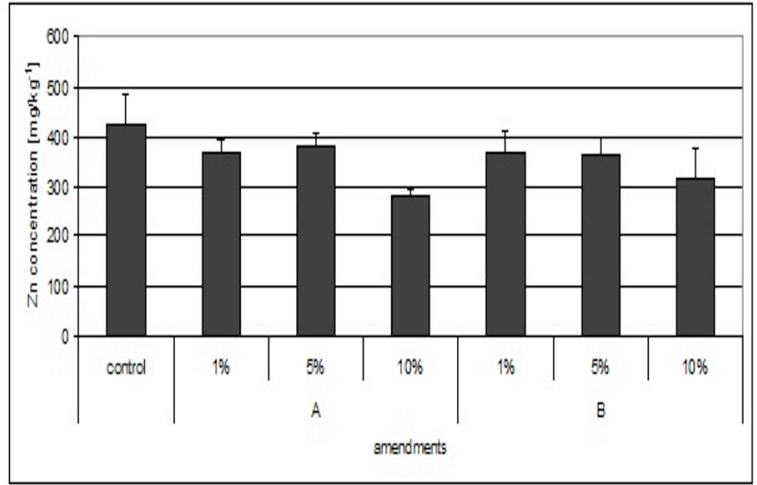

Fig. 7. Content of zinc in plants after application of amendments

Sewage sludge and coal fly ash used in agriculture as soil amendments are the source of organic matter, nitrogen, phosphorus and other macro- and microelements (Chen et al., 2007). Fly ash helps in modulating the soil texture by increasing of silt-sized particles fraction, increases soil $\mathrm{pH}$ and improves soil moisture-holding capacity (Ghodrati et al., 1995). Nonetheless when analysing the adwantages from the sewage sludge usage, the attention should be payed to the possibility of the toxic element accumulation in the soil and soil - plant transfer of contaminats. Participation of alkaline coal fly ash in Slash materials may react as soil heavy metal stabilizer (Wong and Selvam, 2009). The decrease of the trace metal solubility after stabilization 
process with sewage sludge and fly ask was previously observed by Zhang et.al., (2008).

Lower lead, cadmium and zinc values in leaves (Fig. $5,6,7)$ were observed when Slash materials were applied to the contaminated soil. Better results were achieved on variants with the highest dose of material type A. In case of lead decrease of its concentration was visible after introduction of the both amendments to the soil.

\section{Conclusions}

Presented results indicate the possibility of reduction of the level of bioavailability of heavy metals contaminated soils in the vicinity of lead and zinc industry by introducing Slash-type material.

The method allows to reduce the exposure from heavy metals on the area of about $70 \%$. For the rest, application of hard soil technologies should be taken into consideration.

\section{References}

Chen, H., Xub, W., Liuc, J., Zhaod, Q., Heb, Y., Chene, G. Application of composted sewage sludge (CSS) as a soil amendment for turfgrass growth. Ecol. Eng. 2007; 29: 96-104.

Ghodrati, M., Sims, J.T., Vasilas, B.L. Evaluation of fly ash as a soil amendment for the Atlantic Coastal Plain. I. Soil hydraulic properties and elemental leaching. Water Air Soil Pollut. 1995; 81: 349-361.

Gupta A.K., Mishraa R.K., Sinhaa S., Leeb B-K. Growth, metal accumulation and yield performance of Brassica campestris L. (cv. Pusa Jaikisan) grown on soil amended with tannery sludge/fly ash mixture Ecol.Eng. 2010; 36. 8: 981-991.

Houba V.J.G., Van der Lee J.J., Novozamsky I. Soil analysis procedures, other procedures. (Soil and plant analysis, part 5b). Department of Soil Science and Plant Nutrition. Wageningen Agricultural University 1995.

Kucharski R., Marchwińska E., Gzyl J. Agricultural policy in polluted areas. Ecological Engineering 1994; 3:299-312.

Marschner H. Mineral nutrition of higher plants. Academic Press Ltd. London 1995.

Martelli A., Rousselet E., Dycke C., Bouron A., Moulis J.M. Cadmium toxicity in animal cells by interference with essential metals. Biochimie 2006; 88: 1807-1814.

Reynolds K., Kruger R., and Rethman N. The manufacture and evaluation of an artificial soil
(SLASH) prepared from fly ash and sewage sludge. 1999 International Fly Ash Utilization Symposium, Center for Applied Energy Research, University of Kentucky 1999; 1.

Rethman N.F.G., Reynolds K.A., Kruger R. Crop response to SLASH (Mixture of sewage sludge, lime and fly ash) as influenced by soil texture, acidity and fertility. Int. Ash Utilization Symp., Center for Applied Energy Research, University of Kentucky 1999;71.

Sas-Nowosielska A., Kucharski R., Nowosielski O. The use of zinc tolerant plant species for soil pretreatment before lead and cadmium phytoextraction. Fourth International Conference on Soil Monitoring, Brno, Czech Republic 1999; 20-22.

Sas-Nowosielska A., Galimska-Stypa R., Pogrzeba M., Terakowski M. 2010. Evaluation of soil substitutes for remediation purpose prepared as a mixture of sewage sludge and fly ash. Proceedings of 5 th International Conference of Innovative Solutions for Revitalization of Degraded Areas, Poland, Ustron, 6-8 October 2010;136-144.

Sas-Nowosielska A., Kucharski, R., Małkowski, E., Nowosielski, O., Pogrzeba, M. Zinc plant toxicity in process of lead and cadmium phytoextraction. Ochrona Środowiska i Zasobów Naturalnych, Warszawa 2000; 20: 35-39.

Sas-Nowosielska A. Phytotechnologies: Importance in remediation of heavy metal-contaminated soils. in: Khan M. S., Goel A.Z.R. Mussarat J. (eds). Biomanagement of metal-contaminated soils 2011; 277-296.

Truter W.F., Rethman N.F.G., Reynolds K.A., Kruger R.A. The use of a soil ameliorant based on fly ash and sewage sludge. International Fly Ash Utilization Symposium. Center for Applied Energy Research, Univ. of Kentucky 2001; 80.

Wong, J.W.C., Selvam, A. Growth and elemental accumulation of plants grown in acidic soil amended with coal fly ash-sewage sludge co-compost. Arch. Environ. Contam. Toxicol. 2009; 57: 515-523.

Zhang H., Sun L., Sun T. Solubility of iron and trace metals from stabilized sewage sludge by fly ash and alkaline mine tailing. J.of Environ Science. 2008; 20: 710-716.

Zhou Y-F., Haynes R J. Sorption of Heavy Metals by Inorganic and Organic Components of Solid Wastes: Significance to Use of Wastes as Low-Cost Adsorbents and Immobilizing Agents. Critical Reviews in Environmental Science and Technology 2010; 40. 11: 909-977. 